
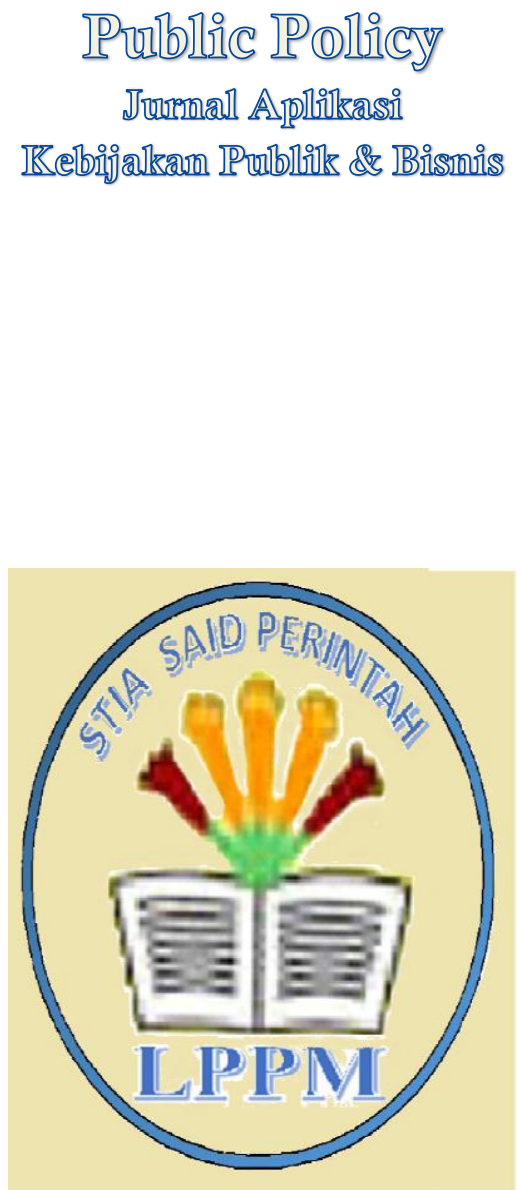

Volume 1, No. 1, Maret 2020

LPPM STIA Said Perintah

stia-saidperintah.e-journal.id

\section{Implementasi Kinerja}

\section{Aparatur Pemerintah Desa}

\author{
(Menurut UU. Nomor 6 Tahun 2014)
}

Fresal Arthur Sopamena

Program Studi Administrasi Negara STIA Saumlaki fresala164@gmail.com

\begin{abstract}
The village government in carrying out the role should be in accordance with the implementation of the duties of the village government as mandated in Law No. 6 of 2014, but in reality the village government failed to implement it to the community.

The results of the research as obtained from the author, and strengthened by observational data, interviews and research conducted, show that the Ridool Village Government in carrying out its activities is not fully in line with the hopes and desires of the Ridool Village community. This is based on the implementation of various village government activities that are not well socialized to the community, even accountability of government activities that are not delivered to the community at all, so that the welfare of the village community served is not in accordance with the demands of carrying out governmental tasks mandated in the Law on Villages.
\end{abstract}

Keywords : Performance, Village Government

\section{Pendahuluan}

Kehidupan Bangsa Dewasa ini mengalami perkambangan yang sangat pesat dari keseluruhan aspek kehidupan manusia, baik dari aspek ekonomi, sosialbudaya, hukum, dan bahkan sampai pada aspek politik yang mempengaruhi kelangsungan kegiatan Pemerintahan disetiap tingkatan yang berbeda. Hal ini tidak terlepas dari tujuan hidup berbangsa sebagaimana dimamanatkan didalam UUD 1945 yakni mensejahterakan kehidupan bangsa, sebagai cita-cita luhur dan semangat hidup berbangsa untuk teteap melakukan perubahan yang lebih baik untuk kemandirian bangsa. 
Sejalan dengan itu, tanggung jawab bangsa dalam mewujudnyatakan kesejahteraan hidup bagi seluruh rakyat Indonesia dalam binkai otonomi daerah mengindikasikan adanya pelimpahan tanggungjawab secara menyeluruh dari pemerintah pusat kepada Pemerintah Daerah. Meski demikian, harus diakui bahwa amanat otonimi Daerah dimaksud dalam undang-undang nomor 32 tahun 2003 belum memberikan jawaban yang khusus bagi pelaksanaan pemerintahan desa sebagai elemen terkecil dari pemerintahan Negara secara Nasional.

Undang-udang nomor 6 tahun 2014 hadir dengan memberikan kemudahan yang khusus bagi pelaksanaan pemerintahan di Desa sebagai bagian dari upaya bersama secara nasional dalam menjawab berbagai permasalahan hidup masyarakat di desa. Dengan dasar itulah, desa hadir sebagai subyek pembangunan yang mengedepankan kepentingan rakyat dalam memajukan dan mensejahterakan sesuai dengan amanat UUD 1945 sebagaimana telah dikemukakan.

Dalam melaksanakan tugas dan tanggung jawabnya, pemerintah desa memiliki kedudukan atau posisi yang sangat sentral untuk mengelola berbagai sumber daya yang ada guna kemajuan desa dan pemberian pelayanan yang maksimal kepada masyarakatnya. Untuk melaksanakan tugas sebagaimana dimaksud tidaklah mudah, akan tetapi bukan berarti hal dimaksud merupakan sesuatu yang sulit dilakukan dalam merealisasikan berbagai kebutuhan hidup masyarakat desa dengan hak dan kewajiban yang dimiliki. Dengan kata lain, tugas dan tanggungjawab untuk memberikan pelayanan berupa pembangunan secara mandiri, transparan dan akuntabel merupakan amanat undangundang yang secara spesifik menjadi jawaban terhadap permasalahan desa yang dihadapi.

Kenyataan yang umum terjadi dimasyarakat bahwa ada petugas pemerintah desa yang mampu secara manajemen dan administrasi untuk memposisikan mereka aparat pemerintah desa yang dapat melaksanakan tugas pelayanan secara maksimal, namun tidak didukung oleh kebijakan desa yang mempermudah mereka untuk menempati posisi pelayanan dimaksud. Atau juga terdapat aparat pemerintah desa yang siap dan mampu mengelola sumber daya yang tersedia di desa guna meningkatkan kehidupan ekonomi dan sosialnya masyarakat, namum tidak didukung oleh kebijakan pemberdayaan masyarakat desa yang secara langsung menyentuh masyarakat secara kolektif dan universal. 
Hal ini tentunya mengindikasikan adanya sikap acuh tak acuh yang ditunjukan oleh aparatur pemerintah desa dalam tugasnya oleh karena mungkin saja dipengaruhi oleh minimnya pengetahuan yang dimiliki terkait tugas yang dipercayakan. Keadaan ini juga berimbas pada adanya sebagian aparatur pemerintah desa yang justru menjadikan statusnya sebagai objek mencari keuntungan semata yang seharusnya tidak dilakukan oleh mereka selaku palayan masyarakat.

Dalam kaitan ini, maka semestinya pemerintah desa memiliki mentalitas melayani masyarakat sesuai tugas pokok dan fungsinya sebagaimana dimanatkan oleh undang-undang, sehingga upaya mensejahterakan masyarakat desa dapat secara perlahan dipenuhi sebagai bagian dari pembangunan desa itu sendiri secara moral. Sehubungan dengan peran yang ditunjukan oleh aparatur pemerintah desa maka Ahmadi Abu, (2009) berpendapat bahwa peran pada hakekatnya merupakan pengharapan manusia yang kompleks terhadap caranya individu harus bersikap dan berbuat dalam situasi tertentu yang berdasarkan status dan fungsi sosialnya. Artinya, manusia dalam setiap sikap dan tindakanya harus dapat memberikan arti, baik lewat sikap, tindakan dan beradasarkan status sosialnya didalam masyarakat. Sementara itu Soejono
Soekanto, (2009) mengemukakan bahwa peran merupakan aspek dinamis kedudukan (status) dimana bila seseorang melaksanakan hak dan kewajibanya sesuai dengan kedudukanya, maka ia menjalankan sebuah peran.

Kedua pendapat diatas terkait dengan status aparatur pemerintah desa sebagai pelayan masyarakat diharapkan dapat menunjukan peranya sebagai pribadi yang bertanggungjawab dengan tugas yang dilaksanakan, sehingga melaluinya masyarakat yang dilayani merasa nyaman dengan pelaksanaan tugas kepada masyarakat. Disadari sungguh bahwa amanat undang-undang nomor 6 tahun 2014 belum mampu diejawantahkan oleh setiap aparatur pemerintah desa dalam memberikan pelayanan yang memadai bagi masyarakat diwilayah desa masing-masing, guna terwujudnya masyarakat yang adil dan sejahtera. Keadaan yang sama tentunya juga dialami oleh masyarakat Desa Ridool kecamatan Tanimbar Utara Kabupaten Maluku Tenggara Barat. Pernyataan diatas sejalan dengan dengan pendapat Noch et al., (2019) menyatakan bahwa efektivitas adalah kondisi atau kemampuan suatu pekerjaan yang dilakukan oleh manusia untuk memberikan manfaat yang diharapkan.

Sebagai desa yang menganut sistim pemerintahan yang defenitif dan terintegrasi 
dari desa lain, aparatur pemerintah Desa Ridool selalu berupaya memaksimalkan pelayanan yang diberikan kepada masyarakat atas dasar kebijakan pemerintah desa yang dibuat. Meski demikian, masyarakat sebagai obyek pelaksana kegiatan pemerintah desa belum sepenuhnya merasa nyaman dengan sistem pelayanan pemerintah desa dewasa ini, akibat dari profesionalisme kinerja aparatur desa yang belum mengutamakan kepentingan masyarakat yang dilayani. Artinya, status yang dimiliki lebih dimaknai sebagai jalan untuk lebih mempermudah urusan masyarakat yang mungkin saja memiliki kedekatan emosional dan lain sebagainya dengan aparat desa. Sebaliknya, masyarakat yang tidak termasuk dalam kategori diatas seringkali tidak mendapat kemudahan dari berbagai keperluan yang diupayakan melalui desa. Diharapkan melalui kajian ini mampu memberi gambaran secara ilmiah menyangkut implementasi kinerja aparatur pemerintah desa di Desa Ridool Kecamatan Tanimbar Utara Kabupaten Kepulauan Tanimbar menurut UndangUndang Nomor 6 Tahun 2014).

\section{Tinjauan Pustaka}

\section{Implementasi}

Implementasi adalah suatu tindakan atau pelaksanaan dari sebuah rencana yang sudah disusun secara matang dan terperinci. Implementasi biasanya dilakukan setelah perencanaan sudah dianggap sempurna. Menurut Usman Nurdin, (2002) dalam bukunya yang berjudul Konteks Implementasi Berbasis Kurikulum menjelaskan bahwa implementasi bermuara pada aktivitas, aksi, tindakan atau adanya mekanisme suatu sistem. Lebih lanjut dikatakan bahwa implementasi bukan sekedar aktivitas, tetapi merupakan suatu kegiatan yang terencana dan untuk mencapai tujuan kegiatan.

\section{Kinerja}

Kinerja menunjuk pada suatu hasil kerja/usaha, dapat berupa prestasi kerja yang diciptakan oleh seseorang (pekerja, pegawai, karyawan, buruh, dll.) dalam suatu proses kerja/usaha yang dilakukannya. Dalam artian ini, maka Pasolong Harbani, (2011) berpendapat bahwa konsep kinerja dapat dilihat dari dua segi, yaitu kinerja pegawai (karyawan) dan kinerja organisasi.

$$
\text { Hasibuan Malayu, }
$$

mengemukakan bahwa kinerja merupakan suatu hasil kerja yang dicapai seseorang dalam melaksanakan tugas-tugasnya yang didasarkan atas kecakapan, usaha dan kesempatan menurut standard yang telah ditetepkan. Dalam hal yang sama maka Sedarmayanti, (2011) berpendapat bahwa kinerja sebagai terjemahan dari 
"performance" berarti hasil kerja dari seorang pekerja, sebuah proses manajemen, atau suatu organisasi secara keseluruhan yang mana hasil kerja tersebut dapat ditunjukkan buktinya secara konkret dan dapat diukur atau dibandingkan sesuai dengan standar yang telah ditetapkan.

\section{Desa}

Desa adalah desa dan desa adat atau yang disebut dengan nama lain, selanjutnya disebut desa, adalah kesatuan masyarakat hukum yang memiliki batas wilayah yang berwenang untuk mengatur dan mengurus urusan pemerintahan, kepentingan masyarakat setempat berdasarkan prakarsa masyarakat, hak asal usul, dan/atau hak tradisional yang diakui dan dihormati dalam sistem pemerintahan Negara Kesatuan Republik Indonesia (PP Nomor 43 Tahun 2014 Tentang Peraturan Pelaksanaan Undang-Undang RI Tahun 2014 Nomor 6 Tahun 2014 Tentang Desa). Berdasarkan batasan Desa, pemerintahan desa dan pemerintah desa sebagaimana amanat UU No. 06 Tahun 2014 diatas, maka Dwipayana Ari, (2003) berpendapat bahwa pemerintah desa adalah sebutan pemimpin Desa di Indonesia yang merupakan pimpinan tertinggi dari pemerintah desa.

\section{Pemerintah Desa}

Desa menurut UU No. 06 tahun 2014 adalah desa dan desa adat atau yang disebut dengan nama lain, selanjutnya disebut Desa adalah kesatuan masyarakat hukum yang memiliki batas wilayah, yang berwewenang untuk mengatur dan mengurus urusan pemerintahan, kepentingan masyarakat setempat berdasarkan prakarsa masyarakat, hak asal usul, dan/atau hak tradisional yang diakui dan dihormati dalam sistem pemerintahan Negara Kesatuan Republik Indonesia.

\section{Metode Penelitian}

Penelitian ini dilakukan dengan pendekatan penelitian kualitatif, guna mengungkap suatu fenomena yang terjadidalam masyarakat atau organisasi pemerintahan. Pendekatan penelitian sebagaimana dijelaskan diatas, selanjutnya akan dijabarkan sebagai sebuah jawaban yang bersifat deskriptif asosiatif guna menjelaskan keadaan yang diteliti. Jenis penelitiannya adalah deskriptif, dimana batasan perundang-undangan tentang desa dijadikan dasar kajian peneliti guna menjelaskan keadaan yang terjadi dan dialami masyarakat.

Untuk menjawab permasalahan penelitian yang diteliti, maka data penelitian yang diperlukan melalui metode pendekatan kualitataif menurut Moleong Lexy, (2012) meliputi data primer (observasi, data wawancara, maupun data lain yang 
ditetapkan peneliti) dan data sekunder (buku dan jurnal). Penelitian ini dilakukan dengan lokus Penelitian yang ditetapkan peneliti berdasarkan permasalahan yang diangkat adalah pada Desa Ridool Kecamatan Tanimbar Utara Kabupaten Maluku Tenggara Barat. Berdasarkan lokasi penelitian sebagaimana ditetapkan, maka yang menjadi unit analasis penelitian ini meliputi;

1. Pemerintah Desa Ridool sebagai pelaksana kebijakan UU

2. Masyarakat sebagai obyek pelaksanaan UU dimaksud, yang mencakup;
a. Tokoh Adat,
b. Tokoh Agama
c. Tokoh Perempuan dan Anak, dan
d. Tokoh Pemuda
e. Masyarakat Biasa

Berdasarkan Jenis data sebagaimana ditetapkan oleh peneliti dan unit analisis data penelitian diatas, maka data penelitian ini diperoleh dari sumber yang dipercaya, yang ditetapkan peneliti sebagai Informan penelitian. Artiinya, masyarakat Desa Ridool dalam penelitian ini hanya memiliki keterwakilan informan yang ditetapkan peneliti, sehingga melaluinya informasi yang diharapkan peneliti dapat menggambarkan keadaan masyarakat secara kolektif. Kemudian data yang dikumpulkan dikaji dengan reduksi data, display data, verifikasi dan kesimpulan. sedangkan teknik validitas data gunakan yakni teknik triangulasi yaitu triangulasi sumber, triangulasi teknik, dan triangulasi waktu.

\section{Pembahasan Hasil Penelitian}

Penyelenggara Kagiatan Pemerintah

\section{Desa}

Berbicara tentang penyelenggaraan Pemerintahan desa oleh pemerintah desa, maka patut dipahami bahwa keseluruhan proses penyelenggaraan kegiatan dimaksud bermuara pada masyarakat sebagai obyek utama pelaksanaan kegiatan pemerintahan desa. Hal ini didasarkan pada konsep pemahaman Desa yang tidak lain merupakan kesatuan wilayah yang dihuni oleh sejumlah keluarga yang mempunyai sistem pemerintahan sendiri. Dengan kata lain, masyarakat sebagai satu kesatuan sistem yang berada pada wilayah pemerintahan dimaksud, harus mendapatkan ruang pelayanan yang memadai dari pemerintahan yang ada untuk menjamin kelangsungan hidupnya.

Kesadaran pelaksanaan fungsi pemerintahan desa oleh pemerintah desa Ridool menurut data wawancara yang diperoleh belum dilaksanakan sepenuhnya menurut undang-undang yang berlaku. Artinya, sistem penyelenggaraan pemerintahan yang tampak melalui kinerja 
pemerintah Desa dalam hal ini, tidak maksimal dijalankan. Dikatakan bahwa

Pemerintah desa sama sekali tidak
mengutamakan uepentingan
masyarakat secara umum unutk
diberikan pelayanan, melainkan lebih
mengutamakan kepentingan diri
sendiri dalam melayani masyarakat.
Hal ini nampak melalui adanya
pengutamaan masyarakat tertentu
yang memiliki hubungan keluarga
dengan pihak pemerintah Desa
tertentu, atau bahkan diberikan
kemudahan pelayanan kepada
masyarakat karena ada imbalan yang
akan diterima (wawancara dengan
Bpk. Welem Kora, S.Pd. (53 tahun)
Sekretaris BPD).
Keadaan sebagaimana disampaikan

oleh informan memberikan suatu ketegasan tersendiri kepada Peneliti bahwa kinerja aparatur pemerintah desa dalam penyelenggaraan Pemerintahan di desa masih menganut paham nepotisme dan keuntungan dalam pelaksanaan kegiatan pemerintahan. Terkait dengan situasi dimaksud, maka masalah ketersediaan sumber daya manusia yang memadai dari aparatur pemerintah desa masih dipertanyakan oleh masyarakat. Dikatakan bahwa;

Tingkat pendidikan seseorang akan mempengaruhi kinerja dari pekerjaan yang dilakukan, sehingga dapat memberikan rasa aman dan kepuasan terhadap orang yang dilayani (Hasil wawancara dengan Ibu Ense Langoru, 42 tahun, tokoh perempuan).
Data wawancara sebagaimana dikemukakan diatas menunjukan bahwa tingkat pendidikan aparatur pemerintah desa yang tidak memadai menjadi alasan tersendiri yang mempengaruhi minimnya pemahaman aparatur pemerintah desa dalam pelaksanaan tugasnya untuk melayani masyarakat.

\section{Pelaksanaan Tugas dan Fungsi Aparatur Pemerintah}

Sebagai satu kesatuan sistem yang menjalankan roda pemerintahan di desa, maka aparatur pemerintah desa dalam pelaksanaan tugasnya senantiasa berpedoman pada proses pelayanan masyarakat yang mengutamakan kepentingan umum. Dalam artian ini, maka kenyamanan dan kepuasan masyarakat terhadap proses pelayanan pemerintah desa akan sangat tergantung pada kesatuan sistem yang memberikan pelayanan dimaksud.

Kondisi pelaksanaan kegiatan pemerintah desa sesuai data diatas semestinya tidak terjadi, karena pada hakekatnya apa yang hendak dilaksanakan oleh pemerintah desa semata-mata untuk kepentingan rakyat. Oleh karena itu, kesatuan konsep pelaksanaan kegiatan pemerintahan memiliki hubungan satu dengan yang lain, sehingga tidak dapat dipisahkan untuk dilaksanakan secara 
terpisah. Hal ini sejalan dengan harapan masyarakat yang disampaikan bahwa;

Kalo dong pemerintah desa bisa kerjasama untuk jalankan kegiatan di desa, maka suda pasti agenda pemerintah yang mau dijalankan tersebut bisa terlaksana sesuai harapan. Tapi yang dong tunjukan itu sama sekali seng menunjukan hubungan kerja yang baik antara masing-masing kepala urusan (Hasil wawancara dengan ibu Adolina Utuwali, 46 tahun, ibu rumah tangga, perwakilan masyarakat).

Kenyataan sebagaimana disebutkan diatas menunjukan bahwa pemerintah desa didalam pelaksanaan kegiatanya tidak berada didalam suasana kebersamaan yang menekankan tentang pentingnya kerjasama yang dibangun.

\section{Implementasi Azas Penyelenggaraan}

\section{Pemerintah Desa}

Amanat Undang-Undang Desa menuntut perlunya kesadaran pemerintah desa dalam memberikan pelayanan yang maksimal kepada masyarakat yang dilayani. Dalam hal ini, pemerintah desa diserahi tanggung jawab yang besar untuk menyelesaikan berbagai permasalahan masyarakat yang berhubungan dengan kenyaman dan keamanan hidup sebagai warga negara. Terkait dengan hal ini, maka sangat diharapkan adanya kepedulian pihak pemerintah desa terhadap berbagai permaslahan yang terjadi yang berhubungan dengan keberadaan masyarakat yang dipimpin secara kolektif. Implementasi asas penyelenggaraan pemerintahan desa berdasarkan data penelitian yang diperoleh sebagaimana telah dijelaskan sebelumnya didalam bab ini, menunjukan beberapa hal pokok yang dimanatkan oleh UU Desa yang belum dilaksankan dengan baik, diantaranya;

1) Tertib Penyelenggaraan Pemerintahan

Penyelenggaraan Pemerintahan yang ideal senantiasa menjadi harapan semua masyarakat yang dilayani. Artinya bahwa masyarakat sebagai obyek pelayanan pemerintahan desa selalu mengharapkan pentingnya perhatian yang diberikan pemerintah terhadap setiap permasalahan kemasyarakatan yang dialami. Dikatakan bahwa pemerintah desa dalam penyelenggaraan pemerintahan masih menerapkan prinsip pemenuhan kepentingan pribadi dibandingkan dengan pemenuhan kepentingan bersama sebagai masyarakat desa. Berdasarkan tertib penyelenggaraan pemerintahan, dikatakan bahwa;

Pemerintah Desa Ridool dalam menjalankan roda pemerintahan selama ini masih menampakan paham Nepotisme, baik dari proses pelayanan yang diberikan, maupun pengambilan kebijakan yang lebih menguntungkan pihak-pihak tertentu yang memiliki hubungan dengan pemerintah (Hasil wawancara 
dengan Bapak Owen, tokoh pemuda).

Pernyataan sebagaimana diatas menunjukan bahwa ruang pelayanan pemerintahan yang diberikan pemerintah desa kepada masyarakat belum sepenuhnya menerapkan proses penyelenggaraan pemerintahan yang ideal. Maksudnya bahwa pemerintah Desa Ridool belum memaksimalkan kegiatan pemerintahan desa yang bersentuhan dengan kepentingan masyarakat umum, diberbagai aspek kehidupan masyarakat.

2) Tertib Kepentingan Umum

Kepentingan Pribadi lebih mendominasi urusan pemerintah dibanding dengan kepentingan masyarakat desa secara keseluruhan yang dilayani. Sehubungan dengan keadaan sebagaimana dijelaskan, maka pada kenyataanya ditemukan bahwa pelaksanaan kegiatan pemerintahan yang lebih banyak bersifat administratif dan mengarah pada kepentingan individu lebih diutamakan didibandingkan dengan kepentingan masyarakat. Hal ini juga tampak melalui pengurusan administrasi yang berhubungan dengan kebutuhan masyarakat sering memakan waktu penyelesaian yang sangat lama. Keadaan ini mengindikasikan bahwa kecintaan tugas yang dipercayakan untuk dilaksanakan sama sekali tidak dimiliki, dan bahkan lebih mengandung unsur nepotisme.

Penjelasan sebagaimana dikemukakan diatas diperkuat dengan data yang diperoleh peneliti yang menyebutkan bahwa; Pemerintah Desa Ridool kurang dan bahkan tidak mencintai atau merasa memiliki tugas pelayanan yang diberikan, sehingga mengakibatkan pembangunan dan perkembangan desa tidak terjadi dan dirasakan oleh masyarakat. Sementara pelayanan yang dilakukan oleh pemerintah desa kepada masyarakat samasekali tidak menyentuh atau memuaskan dan sangat memprihatinkan, bahkan mengandung unsur Nepotisme (Hasil wawancara dengan Bapak Welem Kora, 53 tahun, Sekretaris BPD).

Situasi ini dialami dan dirasakan

oleh masyarakat, sehingga proses pelaksanaan tugas pemerintahan bagi masyarakat setempat masih sangat jauh dari apa yang diharapkan. Kenyamanan pelayanan yang diberikan dalam menjawab apa yang dibutuhkan merupakan dasar pelaksanaan kegiatan pemerintahan yang ideal dan berwibawa.

3) Keterbukaan

Kurangnya keterbukaan pemerintah terkait pelaksanaan kegiatan pemerintahan tampak melalui tidak terlaksanaya berbagai agenda pertanggung jawaban kegiatan pemerintah Desa kepada masyarakatnya. Data sebagaimana telah 
dikemukakan menjelaskan keadaan yang dialami masayarakat di desa, dimulai dari awal perencanaan kegiatan sampai pada pertanggungjawaban kegiatan Pemerintahan sama sekali tidak melibatkan masyarakat secara langsung. Sehubungan dengan hal ini, maka data lain yang ditemukan peneliti dari masyarakat, menyebutkan bahwa;

Pemerintah sama sekali tidak melaksanakan rencana kegiatan yang akan dilaksanakan didalam satu tahun anggaran. Kegiatan yang dilaksanakan seolah hanya bersifat tiba-tiba, tanpa ada pembicaraan sebelumnya dengan masyarakat. Belum lagi, apa yang akan dilaksanakan tersebut tidak pernah disampaikan kepada masyarakat, belum lagi pertanggungjawaban kegiatan yang sama sekali tidak dilakukan oleh pemerintah desa (Hasil wawancara dengan Bapak, Angky 42 tahun perwakilan masayarakat).

Dengan demikian, maka dapat disimpulkan bahwa prinsip keterbukaan sebagai salah satu dasar pelaksanaan penyelenggaraan tugas pemerintahan sama sekali tidak dilaksanakan dengan baik didalam membangun pola kerja pemerintah desa yang bermutu. Hal ini menjadi masalah tersendiri yang hendaknya perlu mendapat perhatian khusus, sehingga masyarakat desa sebagai obejek pelaksanaan setiap kegiatan, dapat merasakan keberhasilan pembangunan yang dijalankan untuk menciptakan masyarakat yang makmur dan sejahtera disetiap bidang.

4) Profesionalitas

Profesionalisme pelaksanaan tugas yang diemban senantiasa hadir dengan berbagai permasalahan yang berbeda, sehingga melaluinya penilaian suatu pekerjaan dapat diketahui seberapa besar tingkat keberhasilan yang dicapai. Dalam arti ini, maka setiap orang dalam melakukan pekerjaanya dituntut untuk profesional dalam bidang pekerjaan yang dikerjakan, sehingga pencapaian hasil yang diinginkan dapat terpenuhi. Sehubungan dengan hal ini, maka hal yang menjadi sorotan masyarakat Desa Ridool terhadap kinerja yang ditunjukan oleh pemerintah desa, menurut mereak sangat ditentukan dengan tingkat pendidikan yang dimiliki.

Pemerintah desa sebagai perpanjangan tangan pemerintah pusat dan daerah didalam menjawab kebutuhan masyarakat senantiasa dituntut untuk harus memiliki pemahaman yang luas terkait dengan kebutuhan hidup masyarakat desa pada umumnya. Keadaan sebagaimana yang diharapkan ini pada kenyataanya jauh dari keinginan masyarakat. Kepekaan dan kesadaran pemerintah terhadap apa yang menjadi kebutuhan masyarakat 
secara umum tidak dimiliki dan ditunjukan oleh aparatur pemerintah desa, sehingga pemerintah secara kolektif dinilai gagal didalam mensejahterakan masyarakanya sendiri. Dijelaskan oleh informan terkait dengan permasalahan ini bahwa kinerja yang ditunjukan oleh pemerintah desa sangat morat marit. Hal ini dikarenakan oleh tingkat pendidikan yang dimiliki tidak sesuai dengan pekerjaan yang dilakukan, sehingga jika mereka tidak memiliki pengetahuan terhadap tugas yang dikerjakan, maka belum tentu ia dapat melaksanakan tugasnya dengan baik (hasil wawancara dengan Ibu Ense Langoru, 45 tahun, tokoh perempuan). Apa yang dipermasalahkan masyarakat terkait dengan pelaksanaan tugas pemerintahan menurut peneliti sangat tepat, dikarenakan tingkat pendidikan seseorang menjadi indikator mutlak dalam menilai pencapaian pekerjaan yang dikerjakan.

Kenyataan dilapangan yang terjadi seuai hasil pengamatan peneliti menunjukan bahwa sebagaian besar kegiatan pemerintahan tidak dapat dilaksanakan sesuai dengan apa yang diharapkan. Hal ini mengakibatkan sehingga posisi pemerintah desa sebagai perpanjangan tangan pemerintah pusat dan daerah tidak dapat melaksanakan fungsinya dengan baik untuk menjawab kepentingan masyarakat yang dialami. Dengan kata lain, kegagalan pelaksanaan kegiatan pemerintahan baik yang bersifat administratif, maupun yang bersifat teknis tidak terlaksana sesuai harapan dan keinginan masyarakat, karena tidak didukung oleh ketersediaan sumber daya aparatur pemerintah Desa yang memadai.

\section{Kesimpulan Dan Saran}

\section{Kesimpulan}

Berdasarkan paparan pembahasan hasil penelitian diatas maka kesimpulan hasil kajian ini antara lain sebagai berikut;

1) Belum sepenuhnya menjalankan sistem penyelenggaraan Pemerintahan yang ideal sebagaimana yang diamanatkan didalam Undang-Undang tentang desa.

2) Bahwa asas penyelenggaraan pemerintahan desa belum maksimal dilaksanakan, sehingga pelayanan yang diberikan terkadang masih bersifat individual semata.

3) Bahwa kurangnya antusiasme pemerintah desa dalam melibatkan masyarakat pada setiap agenda pelaksanaan kegiatan, mengakibatkan masyarakat bersikap apatis (masa 
bodoh) dengan dalam mendukung pelaksanaan kegiatan pemerintahan.

4) Pemerintah Desa harus dapat merencanakan dengan baik pelaksanaan kegiatan yang akan dijalankan sebagai bentuk pertanggungjawaban tugas kepada masyarakat, sebagaimana yang diamanatkan didalam UU Nomor 6 tahun 2014 tentang desa.

\section{Saran}

Berdasarkan kesimpulan hasil penelitian diatas, maka beberapa hal yang direkomendasikan sebagai masukan antara lain;

1) Pemerintah Desa Ridool harus bersikap kooperatif dalam melaksanakan kegiatan-kegiatan Pemerintahan, baik dengan masyarakat desa, maupun dengan pemerintah yang setingkat diatasnya untuk memaksimalkan kegeiatan pemerintahan yang dijalankan.

2) Pemerintah Kecamatan harus dapat memberikan pengawasan melekat kepada Pemerintah Desa Ridool, sehingga kegiatan pemerintahan yang dijalanakan haruslah mengarah pada kepentingan masyarakat desa secara kolektif.

3) Masyarakat hendaknya dapat bersikap kritis terkait dengan penyelenggaraan Kegiatan Pemerintahan Desa senagaimana diamanatka didalam
Undang-Undang tentang desa, khususnya dalam mengawal jalanya kegiatan pemerintahan desa yang mengarah pada pemenuhan kepentingan bersama sebagai warga masyarakat Desa Ridool.

\section{Daftar Pustaka}

Ahmadi Abu. (2009). Psikologi Umum. Jakarta: Rineka Cipta.

Dwipayana Ari. (2003). Membangun Good Governance di Desa. Yogyakarta: National Institute for Research Advancement.

sHasibuan Malayu. (2002). Manajemen Sumber Daya Manusia. Jakarta: Bumi Aksara.

Moleong Lexy. (2012). Metodologi Penelitian

Kualitatif. Bandung: PT Remaja Rosdakarya.

Noch, M. Y., Pattiasina, V., Rumasukun;, M. R., Patiran, A., \& Nusi, Y. F. N. (2019). Statistical effectiveness of village funds allocation for improving village development in Papua, Indonesia. Journal of Advanced Research in Dynamical and Control Systems, 11(10 Special Issue), 1204-1209. https://doi.org/10.5373/JARDCS/V11SP 10/20192964.

https://www.jardcs.org/archivesview.php

?volume $=1 \&$ issue $=21 \&$ page $=5$ 
Pasolong Harbani. (2011). Teori Adiministrasi Publik. Bandung: Alfabeta. Sedarmayanti. (2011). Manajemen Sumber Daya Manusia, Reformasi Birokrasi dan Manajemen Pegawai Negeri Sipil (Edisi Keli). Bandung: PT. Refika Aditama.

Soejono Soekanto. (2009). Pembangunan Dalam Zona Pemerintahan. Bandung: Gelora Akira.

Undang-Undang RI. Undang-Undang Nomor 6 Tahun 2014 Tentang Desa. , (2014).

Usman Nurdin. (2002). Konteks Implementasi Berbasis Kurikulum. 2002: CV. Sinar Baru. 